\title{
Embracing Customer Relationship Management (CRM) to Improve Organisational Viability by Small Businesses in Chinhoyi, Zimbabwe
}

\author{
Gudyanga Ayiri ${ }^{1}$, Gondo Kudzanayi ${ }^{2}$ \\ ${ }^{1,2}$ Zimbabwe Open University, Faculty of Commerce and Law, Mashonaland West Regional Campus, Zimbabwe
}

\begin{abstract}
The study aimed at finding ways of improving organisational viability by small businesses in Chinhoyi through applying Customer Relationship Management (CRM). This study was prompted by lack of growth of the sector. These firms have been facing a business environment characterised by low Gross Domestic Product (GDP), foreign currency challenges, high unemployment, brain drain, liquidity crisis, high competition and low demand for domestic products. The descriptive design was used. Thirty registered small businesses, with approximately 100 subordinates and 25 managers/supervisors formed the target population for the study. The sample size was 40 and comprised of 30 subordinates and 10 managers/supervisors. Simple random sampling was used to select respondents for the study. The research instruments used were questionnaires, observations and interviews. The study found out that many small businesses do not have a comprehensive CRM programme. The study concluded that lack of a comprehensive customer relationship management programmes by small businesses has been hampering performance of the sector. The study recommends the implementation of CRM programmes by small businesses in Zimbabwe through information centres and embracing information technology. Feedback processes are also necessary for CRM. There is need to carry out a national survey on CRM for small businesses for generalisation of findings across the entire Zimbabwean economy.
\end{abstract}

Keywords: Customer Relationship Management, Organisational viability, Small businesses

\section{Introduction}

Small Businesses are enterprises employing 6 - 40 people, with a maximum turnover/ sales of $\$ 500000$ - $\$ 1500000$ and a maximum of Gross Asset value of $\$ 1000000$ (Zimbabwe SMES Act, Chapter 24:12. These enterprises account for 60\% of productive activities in Chinhoyi Urban (Fin Scope Survey Zimbabwe, 2012). These small businesses have been experiencing serious challenges (Karedza et al., 2014). Management and marketing have also become a thorny issue as the small firms fight to survive and at the same time try to increase revenues and profitability. At face value, most small businesses are struggling to survive. They face stiff competition from micro, medium and large scale enterprises. The Fin scope survey Zimbabwe (2012) indicated that, the majority collapse and fold in the first five years of existence. However to alleviate the adverse impact of the marketing problem, and from a literature point of view, small businesses could achieve success, if they seriously embrace the Customer Relationship Management (CRM) approach. For example, Henrick (2008) shows that there is numerous evidence that a close relationship between customer commitment and profit levels. The profit increases with the more time spend with the firm.

CRM brings more interactions between buyers and sellers so as to improve customer loyalty and sales (Etzel et al., 2004). CRM establishes multidimensional connections between supplier and customers so that they relate as serious partners in business. In such situations, there should be more understanding (reciprocity) between buyers and sellers. Sometimes, mass customisation, which involves production or selling a variety of products mainly in response to the complexity and diversity of customer needs, is necessary to give these customers freedom to choose (Jobber, 2001). This brings more chances, not only for loyalty, but boosts more revenue under such conditions. Thus, given the scenario in which the businesses operate and their nature (size and limitations), the focus of the study was to examine how small businesses in Chinhoyi could seriously embrace customer relationship management to boost sales and improve viability.

\section{Literature Review}

CRM is one of the most important factors of success in any modern organization (Raab et al., 2008). There are many benefits to accrue to small businesses that embrace CRM seriously. A good CRM helps improve customer satisfaction and customer perceptions about a firm's product (Penstone, 1999, Etzel at el., 2004). This is very important where clients are in doubt and reluctant to deal with small businesses due to their shortcomings especially for bigger, expensive products. Even for long term strategies, CRM assist firms to focus for the future (Cateora and Graham, 2003). The more time the small business spend in interacting with the customer, means more trust, greater customer perceptiveness and high mutual commitment between them 
(Henrick, 2008). Intuitively, CRM creates sustainable comparative advantages to businesses in the long term (Raab, at el., 2008). The obvious results of CRM are high sales growth, more profits and operational viability. This is necessitated by high customer satisfaction, customer loyalty, new customers referred by existing satisfied customers. Customer satisfaction is the measure of how the needs and responses are collaborated and delivered to exceed customer expectations. Relationship building is a precursor to customer satisfaction. Customer loyalty is also promoted by constant feedback on customer requirements, which result in excellent service and performance of the product (Chaston, 1990).

The other benefit of CRM to businesses is cost reduction. By integrating effectively, all the needed information sources and systems of customers (data warehouses or banks) means the behavior of customers are better interpreted (Cravens and Piercy, 2003). These customer data warehouses, supported by competitor intelligence systems provide vital information cheaply and are easier to mine (data mining) i.e. extracting relevant information on customer behavior in a competitive environment is easier. On the other hand, to serve a loyal customer and old customers is easier as compared to new ones. Etzel et al., (2004) stated that research confirmed that repeat sales are six times less expensive to make than a sale to a new customer. This is because their characteristics may not be easy to understand. CRM as a marketing approach involves meeting exceedingly customer expectations through understanding customers in depth (Butler, 2004). In a nutshell, CRM serves to manage a firm's current and future customers through deep interactions. CRM envisages practices, strategies and technologies that companies use to manage and analyse customer interactions and data throughout the customer lifecycle, with the goal of improving business relationships with customers, assisting in customer retention and driving sales growth (Cateora and Graham, 2003). The whole process involves capturing all customer data, maintaining it systematically and using this data to retain or create more customers. Solid relationships are established and managed through definite programmes like promising to meet certain customer specifications and expectations (George, 2006). Organisations should manage their customers well through the introduction of reliable systems (Etzel et al., 2004). Reliable systems are trusted and help establish user friendly processes and procedures that are long lasting. Thus meaningful relationship between supplier and buyer should be a continuous process that involves a series of synergistic episode of interaction many a times to create mutuality and interdependency between two people. Continuous relationship requires absolute trust and commitment by both parties (Payne et al., 1995; Kotler and Bowen, 2006).

Developing a relationship is a process which requires skill. Buttle (1996) suggested ways in which a meaningful relationship can develop. These ways are:

- Exploration - The customers familiarises with the product over time. Once satisfied the customer-suppler relationship grows.

- Awareness - The customer appreciates the value assigned to the product by the supplier.

- Expansion - The customer becomes more oriented to a firm's product and is always ready to buy more of the product.

- Commitment - Commitment is a powerful stage when suppliers learn to adapt business rules and goals to excel.

- Dissolution - This signifies the end of the relationship due to various reasons. The reason for dissolution could be either from the customer or the supplier's side. This could be triggered by change of preferences on the customer's part or change of product specifications on the supplier's part.

Customer information is central to marketing (Adcock et al., 2001).The firm should understand, customer trends, behaviour, preferences and changing circumstances. Of course, as already indicated, this should be backed by competitor information. Competitor information should show all the relevant information pertaining to their products, strategies and why customers buy their products. For a firm to benefit much from CRM, they should have appropriate CRM systems in place. This helps them to analyse customer data properly, forecasting and choosing relevant CRM tools for the firm. These systems cover strategic CRM or analytical CRM, operational CRM and collaborative CRM (Kotler and Bowen, 2006). The strategic CRM focuses on maintaining long-term relationships with customers through various programmes. The aim of strategic CRM is to concentrate and enhance the knowledge about customers and use this knowledge to improve and customise the interactions with customers to maintain a long-term relationship with them. Operational CRM system has three key components namely sales force automation, marketing automation, and service automation (Etzel, et al., 2004). Operational CRM system involves making routine marketing operations like service calls, service programmes and customer activities (Etzel, et al., 2004). Analytical CRM uses various data sources to get information for use by different stakeholders in the organisation. Common methods are demand estimation and forecasting techniques like data mining, regression analysis or pattern-recognition. Collaborative CRM is comprehensive and involves both internal and external stakeholders in sourcing informing and determining the relationship. Collaborative CRM promotes customer interactions via media, advertising, brochures or printed catalogue. Once these systems are crafted by individual firms then they could develop or select appropriate CRM software tailor made to meet their specifications. This software helps synthesizing and putting customer information into one place making it easier to use. 


\section{Methodology}

The descriptive design was adopted for this study. The target population comprised 30 registered small businesses, with approximately 100 subordinates and 25 managers/supervisors. From 30 registered small businesses, 10 were chosen randomly to draw a sample size of 40 comprising 30 subordinates and 10 managers/supervisors. Questionnaires, observations and interviews were used to gather data from respondents. The data collected sought to provide answers to the following research questions;

- To what extent is CRM practised by small businesses?

- To what extent are small businesses benefitting from CRM?

- What are the constraints faced by small businesses in implementing CRM?

\subsection{Application of CRM by small firms in Chinhoyi}

\section{Results And Discussion}

The small businesses show mixed effort in implementing CRM. The firms were putting minimum effort in updating their data for customers as shown by majority respondents of $60 \%$ who indicated that. At the same time $60 \%$ also indicated that most of the businesses are not supporting CRM programmes. However the after sales services and customer delivery processes with $57 \%$ score tends to reflect some effort in meeting customer satisfaction. The majority of the ten managers/supervisors interviewed indicated that though, they are trying their level best, they are not very skilled in customer relationship management.

Small businesses, naturally, and through experience really understand the need to create and retain customers. This is the source of their revenue and profitability. However, as revealed by the findings, their effort is blurred by not taking the processes seriously during implementation. For example, poor data management systems for customers, means poor tracking and lack of proper feedback. As Cravens and Piercy (2003) indicated, CRM systems are purely designed to effectively capture all customer information for the betterment of the organization. Should this fail, then challenges manifest for instance customers get frustrated, especially when there is no change in product quality or where mass customisation was expected (Jobber, 2001). Even lacking proper CRM management approach means limited realisation of benefits of CRM by small businesses. Surprisingly they tend to fair much in after sales services and customer delivery processes which is critical in that some of the products or inputs in producing the final product are highly external. Some workers tend to link with customers to help them during their spare times and get some extra cash.

\subsection{The extent to which small businesses are benefitting from CRM}

Findings revealed how CRM is benefitting small businesses. Fifty percent felt that CRM is helping them to focus for the future. In terms of revenue contribution there was only a 58\% contribution. The findings also suggest that profitability is compromised by uncontrolled costs partially due to poor exercise of CRM. On the overall the small businesses sector lags behind in implementing CRM. From the ten interviewed management respondents, it was noted that small businesses in Chinhoyi are not very serious about implementing CRM programmes but resort to clandestine methods to win customers in the environment because of its volatility and other constraints.

Findings revealed that most of the small businesses using CRM on average are benefitting. This confirms what Kotler and Bowen (2006) suggested that CRM could benefit firms even where there is stiff competition. Those benefitting much said it was mainly through customer loyalty. Creating meaningful relationships and meaningful customer service experience, induces loyalty and great desire by customers to come back (Trauer and Ryan, 2005). Some try to make them feel more special and give them the attention they desire (George, 2006). Concentrating on existing customers is relatively cost-effective as compared to trying to get new ones and work for loyalty. This is in line with what Etzel et al., (2004) assert, that it is cheaper to deal with existing customers than new ones. Though, only $40 \%$ of the respondents cited CRM as contributing to reduction of costs the majority have not yet fully captured the approach. To those who apply CRM, it gives them the knowhow and skills to deal with customers effectively and efficiently. This is important in that most of them lack basic training. The small businesses also have an edge over micro enterprises which many pose a threat to their survival and growth. As a source of an organisation's competitive advantage, CRM helps them outwit micro enterprises by prioritizing customer needs and customizing their products and services to exceed customer expectations as compared to competitors (Parasuraman and Botha, 2006). This works well if small businesses have sufficient knowhow on how to apply CRM. As already indicated above, $75 \%$ of the respondents felt that they do not have enough knowledge on how CRM works. Knowing CRM enables small businesses to understand and prioritize the needs of customers and to customize their products and services to meet and exceed their expectations. This creates competitive advantage over competitors who may be doing business with little understanding of CRM. Businesses with long-term customers are more stable and are likely to benefit much from their strategic plans. For example, this enhances stability in demand in the long run and at the same time helps these firms to position themselves meaningfully (George, 2006). 


\subsection{Constraints in implementing CRM}

Research findings revealed that various constraints in implementing CRM existed. The greatest constraint was the liquidity crisis, followed by limited finances and poor knowledge. The majority felt that the liquidity crisis was severely affecting the viability of small businesses. Limited finances further exacerbated the ability to have a viable customer relationship management programme were recent technologies may be required.

\section{Conclusion}

The study concludes that small firms are not fully applying CRM. Hence, this lack of comprehensive CRM programmes in small businesses had been hampering their ability to maximise the operational viability of the businesses. This has brought in limited benefits of CRM to the sector as the small businesses instead, resort to other methods of winning customers. Others are applying CRM without understanding the real concept of the approach. However, in spite of the many challenges they face, mainly because of their sizes, there is still great potential for the small firms to grow if they take CRM seriously. Poor finance base and knowhow pose great challenges in their efforts to effectively implement CRM programmes

\section{Recommendations}

In light of the above conclusions, the study recommends the following measures for implementation if small businesses are to yield high rewards from CRM;

\section{- Information Centres}

Small businesses should seek relevant information and establish information centres. This they could do through forming a formidable association with line ministries and other stakeholders. They could use synergies so that they pool resources together, sharing ideas on market trends and customer requirements.

\section{- Information technology}

Small businesses should take information technology seriously. They should take advantage of Science, Technology and Engineering initiatives by the government. This is a deliberate programme by central government to develop the economy through promotion of science, technology and engineering as a roadmap for socio-economic development in Zimbabwe. These initiatives by government help small businesses to reengineer their business processes and enhance customer satisfaction though quality services and products, product availability as well as affordability.

\section{- Feedback processes}

There should be strong feedback mechanisms. Feedback involves costs, effort and time. Small businesses should take this seriously and make the necessary adjustments required. Where necessary, especially in the retail trade where they have little input in the product they are selling, they need to give the correct information and be close to final users of products. This will help retain more customers.

\section{- Training}

There is need to continually train staff and owners, managers/supervisors of small businesses on CRM. This is necessary since customer characteristics are dynamic. In addition, the world environment is also changing including the products and their specifications and thus having severe implications on CRM.

Finally it is recommended that a national survey on CRM for small businesses be undertaken for better generalisation of findings across the entire Zimbabwean economy.

\section{References}

[1]. Aaker, D. Kumar, V. \& Day, G. (2004). Marketing Research ( $8^{\text {th }}$ Edition). New York: John Wiley.

[2]. Adcock, D, Halborg, A and Ross, C (2001). Marketing Principles and Practice. Gasport: Ashford Colour Press Limited.

[3]. Brunt, P. (1997). Marketing Research. Oxford: Butterworth-Heinemann.

[4]. Cateora, P. Graham (2003). International Marketing. New Delhi: Tata McGraw-Hill.

[5]. Chazuza, T., Mutengezanwa, M (2011). An analysis of the impact of targeted government Support on SMEs growth and development in Zimbabwe: a survey of Mashonaland Central Province. Journal of Research in International Business Management. (ISSN: 51-0028) Vol. 2(2) pp. 051-059 February, 2012. ISSN 2222-1905.

[6]. Cooper, D. \& Schindler, P. (2006). Business Research Methods ( $9^{\text {th }}$ Edition). Harlow: Prentice Hall.

[7]. Cowell, D. (1984). The Marketing of Services. London: Heinemann.

[8]. Cravens, D.W, Piercy, N.F. (2003). Strategic Marketing ( $7^{\text {th }}$ Edition). McGraw-Hill Irwin.

[9]. Drucker, P.F. (1969). The Practice of Management. London: Heinemann.

[10]. Etzel, M.J. Walker, B.J and Stanton, W.J. (2004). Marketing (13 ${ }^{\text {th }}$ Edition). New York: McGraw-Hill.

[11]. Farrell, C.M.( 1999). Fundamentals of Selling (6 ${ }^{\text {th }}$ Edition). Boston: Irwin McGraw Hill.

[12]. George, P. (2006). The Principles and Practices of Promotion. New York: Irwin

[13]. Government of Zimbabwe (2004). Small to Medium Enterprises Act [Chapter 24:12]. Harare.

[14]. Fin Mark Trust. (2013). Fin Scope Zimbabwe Small Business Survey 2013. Harare 
[15]. Henrick, V. (2008). Customer Relationship Management. Hamburg [Germany] : Diplomica Verlag.

[16]. Jobber, D.(2001). Principles and Practice of Marketing. New York: McGraw-Hill.

[17]. Karedza, G. Sikwila, M. Mpofu, T. And Makurumidze, S. (2014). An Analysis of the Obstacles to the Success of SMEs in Chinhoyi, Zimbabwe. European Journal of Business and Management. Online) Vol.6, No.6.pp 40.

[18]. Kotler and Armstrong. (2004). Principles of Marketing (4th Edition). New Jersey: Prentice Hall

[19]. Levitt, T. (1960). Marketing Myopia. Harvard Business Review, July/August: 45-56 \& Sons

[20]. Laws, E. (2002). Marketing: Quality and Services Management Perspectives. London: Continuum.

[21]. Masola, M. 2004. Zimbabwe on the Map. The Financial Gazette, 7-13 May:21

[22]. McCarthy, E. \& Perrault, W. (1988), Essentials of Marketing. Homewood, Illinois: Irwin.

[23]. Msipah, N. Chavunduka, D.M., Jengeta, Mufudza and Nhemachena, T: (2013) Journal of Sustainable Development in Africa (Volume 15, No.2, ISSN: 1520-5509

[24]. Penstone, K. (1999). It's Business It's Personal. Marketing Mix. 17(7), July.

[25]. Raab, G, Ajami, R.A, Cargrya, Coddard, C.J. (2008). Customer Relationship Management: A Global Perspective. Aldershot: Gower (eBook)

[26]. Simmons, M. R. (1997). "Customised Marketing." Internal Marketing December: 68-73.

[27]. Vegter, I. ( 1999). The Mile High Club. Marketing Mix. 17(8), August

[28]. Wilmhurst, J. (1993). Below The Line Promotion. St Ives: Butterworth.

[29]. Zimbabwe Revenue Authority. (2014). Special Initial allowances to Small to Medium Enterprises, Harare: Government of Zimbabwe. 